\title{
From Physician to Patient: a Personal Journey
}

Colin Powell, MB, FRCP

Professor of Geriatric Medicine (retired), University of Calgary, Calgary, AB

DOI:https://doi.org/10.5770/cgj.20.287

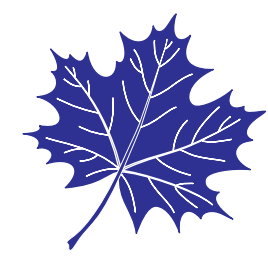

\begin{abstract}
Going from physician to patient is a journey from which few of our tribe will be spared, and about which we have comparatively little formal reflection. This paper describes some of the lessons learned on such a journey from a retired Professor of Geriatric Medicine, whose course of vascular parkinsonism offers lessons both professional and personal.
\end{abstract}

Key words: retirement, parkinsonism, aged, physician, geriatric medicine

In 2015, I was invited by the Calgary Chapter of the Alberta Association on Gerontology to deliver an address entitled, "The Innermost Journey of a Geriatrician with Parkinson's Disease". I took the liberty of changing this title to, "From Physician to Patient: a Personal Journey".

This was the first address to a health-care audience since I retired in 2013. I was both wary and pleased to be invited; I found it a challenge to my current cognitive function! On a point of personal clarification: I do not have classic Parkinson's disease. I do have vascular parkinsonism (i.e., features of PD attributable to a specific cause). Some people call vascular parkinsonism "lower body parkinsonism"symptoms and signs largely affecting the legs rather than the arms and presenting often symmetrically, rather than asymmetrically, as in classic Parkinson's disease. Problems with tremor are usually less troublesome, whereas problems with gait and posture can be obvious: this is my predicament.

My talk covered three areas: who I am, my life as a physician, and my personal transition from physician to patient. I began by posing two questions to the audience. A common expression is "old age is not for sissies". Can you think of an alternative, contemporary expression? Also, what do patients feel when going through the system and what can you do as a health-care professional to help?

So, who am I? Given my age, gender, and generation, the answer is, "I am my job"! I grew up in east London, England. I'm a cockney and, although a cockney is one born within the sound of Bow Bells, when I was born they were silent because of the War. My kids would describe me as both a "jock" and a 'nerd'. As a jock, I played rugby football and did a lot of running. Later I became a race walker, being self-taught from the Internet; my best times were $5 \mathrm{~K}$ in 35 minutes. As a 'nerd' I was, and still am, a "bookworm", preferring the real thing to Kindle.

I started medical studies at age 17 at Charing Cross Hospital, University of London and qualified at 21. I was immediately looking after various desperados and others in the Accident \& Emergency and in-patient wards. I was then on call and working a 100-hour week and earned half the rate of the hospital head porter! I initially intended to be a family doctor, so had further experience in pediatrics and obstetrics. I then decided to become an internist and studied Internal Medicine in Oxford and later Glasgow.

Why do people become geriatricians? It's not for the money! Generally, there are two common reasons-and both applied to me. Firstly, close contact with old people, and secondly, the presence of a role model or an exemplar in one's professional training.

I visited my granny most weeks and she lived with us for the last year of her 76 years. I remember distressing her with my habit of walking round and round her kitchen table, talking non-stop: "Please stop Colin, you're making me dizzy!"

My role model was Mike Rout, my Senior Registrar at Oxford. I learnt a lot from him about how to care for old people, their families, and professional carers. After a few months, I realized that geriatricians looked at old people in a different way from the rest of general hospital medicine. There, the usual objective was to get patients out of hospital as quickly as possible, often with early, perhaps too early, admission to a nursing home or long-term institutional care. I realized I wanted to be part of that different style of care. I completed my training in internal then in geriatric medicine and began 50 years as a geriatrician.

Secondly, my life as a physician. Two key people, influential in the world of geriatrics when I started, helped me to see geriatrics as an alternative way of doing medicine, indeed seeing it as a calling. They were Dr Bernard Isaacs and Professor Sir Ferguson Anderson who was the first Professor of Geriatric Medicine in the world. Ben Isaacs had about 10 ideas a day and as his Fellow, I had to review and explore them all-very educative and exhausting. (I've worked for people who have had one idea in a professional lifetime!) I remember at the appointment interview, he asked me: "Tell me in one word what you are trying to get across to medical 
students about health care of the elderly?" (As an aside, let's get personal, what would your word be?) My reply was "enthusiasm". I can see Ben's face now. He smiled and I knew I had the job. I worked in Glasgow, then in Liverpool, in both serving older people in socially deprived areas.

I came to Canada at the invitation of the Government of Alberta to teach a course for public health nurses in Edmonton. Naively, I did not realize this was a recruitment exercise! I was later offered the Headship of Geriatric Medicine at the University of Manitoba, and ten years later became University Head at Dalhousie in Halifax, then in Calgary until I retired in 2013. From the early 80s, I was an active member of the Canadian Association on Gerontology (CAG) and at one point served as Chair of the Health and Biological Sciences division of CAG. My approach as a geriatrician was to embrace the biopsycho-social model of health care of the elderly, particularly in its multidisciplinary format.

I have thought about what was important to me and the things I really cared about in my geriatric practice. A foundational facet was the importance and relevance of home visits. Whenever a student from any health-care discipline was assigned to me, I would take them on a home visit (a house call, to use the North American term). Some of these patients and locations I well remember to this day.

One elderly couple, both dementing, I visited with a community social worker in an isolated seaside Nova Scotia location. They both needed comprehensive cognitive and physical assessment not available other than by transporting both subjects to Halifax. I am not sure whether they had ever been there; both were readily paranoid and would have refused this trip. Fortunately, the social worker and I were able to assess their problems, the principal one was a concern that a landowner was after their cottage and land! I thought this may well be the case. Another visit was to Stoney Mountain Federal Prison. A prison cell is not an ideal location for a frail elderly person, particularly one who required walking frames and other mobility aids. Some USA prisons have developed geriatric units in response to this specialized demand.

Another issue that confronted me when I started was the widespread use of physical restraints. To put it bluntly, I was appalled. I had never seen this done before in any geriatric service in the UK. Another British geriatrician visiting Canada commented: "In Britain we tie up dogs, in Canada they tie up people!" We later did a study, published in the CMAJ in the 80 s. $^{(1)}$ One of the co-authors, a Clinical Nurse Specialist colleague, later presented our work to a USA congress committee on aging and, as a consequence, US funding laws were changed so that recipients of US federal funds had to reduce or abandon use of physical restraints.

I developed a clinical interest in Parkinson's disease. Following a year as acting Head of Internal Medicine at Dalhousie, I negotiated with the Dean of Medicine to undertake a sabbatical. I saw a gap in how we - the health-care system - cared for elderly people with Parkinson's disease (PPD). This was attractive to a geriatrician because of links with rehabilitation, drugs, clinical medicine, and cognition, and so I undertook a sabbatical in Edmonton and Vancouver. This became a sub-specialty of my practice. I then forged a relationship with the Parkinson Society and taught for them in British Columbia, Alberta, and Nova Scotia. We published in a general internal medicine journal. ${ }^{(2,3)}$ I have always had a love of teaching both as a lecturer and in small groups.

My wife commented I was practicing "patient- and family-centred care". When in Nova Scotia I employed a new procedure. Every consultation letter I sent to a family doctor following a request to see a patient was copied to that patient (I felt strongly this was the patient's information). Over a period of 10 years I can recall only four instances of the patient or family objecting to the content of the letter. Conversely these letters often empowered patients and family (e.g., the daughter reminding the family doctor of my consultation therapeutic suggestions).

Another practice to which my wife introduced me was ask one question. At the end of my consultations, I asked patients and the accompanying family: "Is there anything that could have gone better for you today?" One daughter bluntly responded, "You could have turned up on time!" I later discovered that we had been asking patients to attend about 30 mins before I was available! This was rapidly corrected to the subsequent benefit of the patients and their families.

My next question for you to think about is: How do you engage older people to recognize their feelings as they journey through the health-care system?

I'm now going to talk about my transition from physician to patient. It was a profound change of roles, from being a person with answers to a person with questions! It was abrupt, unplanned, and unforeseen! I've already mentioned my problems with gait and balance because of vascular parkinsonism. I also have some memory issues and word finding difficulties, and this precipitated the need for diagnostic assessment.

Now, let me tell you a story of being on the receiving end of cognitive testing. I hated it and still do. It is so unpleasant and yet I put so many patients through it. The Albert Medical Association was very helpful in facilitating that this assessment was done in Edmonton because of my sensitivity and embarrassment of having it done here in Calgary. I knew many of the practitioners, indeed had taught some. We're part of a small community in health care and, as it turned out, the physician that I saw had been a former resident of mine in Halifax. I had forgotten but apparently, at the end of the six months she spent with us, I had written her a personal letter saying how much I had appreciated working with her and wishing her the best in her future professional career. She reminded me of this contact and indeed had kept the letter. So the moral of this story is to be kind to your residents, because you never know when $\mathrm{X}$ years later they are the ones assessing your brain.

These changes in roles and viewpoints were particularly poignant because of my clinical interest in cognitive 
impairment and Parkinson's disease in old age. When I used to lecture on the trajectory of chronic illness, I quoted Corbin and Strauss: ${ }^{(4)}$ "When a severe chronic illness comes crashing into someone's life, it cannot help but separate the person of the present from the person of the past, and affect or even shatter any images of self, held for the future."

Ann, my wife, commented that this journey was bittersweet, although from her perspective there was not much sweetness at times. She had a hard time initially accepting the perceived "unfairness" of it all and has been my protector since.

Especially recently I have had to confront the reality of a "contracting world". I had become carless, although before this I had been out and about every day. A few weeks ago following an occupational therapist's assessment home visit, I was prescribed a walking frame. Both these events confirmed that my environment was contracting as my disabilities increased. There was an ongoing impact on our life and relationships. We could no longer hike together, all travelling was affected, and we became dependent on others for simple trips for nearby shopping. Day-to-day life was disrupted, with consequent wife-husband, carer/ care-receiver tensions.

All this faced me with the challenge of "practicing what I preached". For example, it had been a common part of my practice to advise cessation of driving with removal of a driving licence. You will recall that delicate plant of the male ego which must be cherished on all occasions; if you wish to destroy this plant then, remove his driving licence! I would sometimes advise planning to give up the licence in the ensuing three or four months, giving time to plan and make budgetary adjustments. This can leave the decision in the subject's control and often thwart or avoid the family's plans and subterfuges.

In any exercise program aimed at seniors, the importance of routine exercise is an effective antidote to ageing. This easy to say but hard to practice, especially when one is not seeing rapid results. I found this to be the case when I started to neglect regular exercise. I recently joined an exercise program for patients with parkinsonism under the auspices of the Parkinson's Society. This is for one hour thrice weekly for 10 weeks. Already my walking, balance, and demeanour have improved.

I was challenged to cope in the face of progressive disease and continuing losses, including that of selfimage. I've always found it hard to express and process feelings (given my gender, age, ethnicity-after all, I am a Brit). When Ann and I were going through the diagnostic assessments, I had never realized how much my patients and their spouses would have wept before they saw me. As we reflected together in preparation for this talk, the factors which have helped me through these times are: humour; "Trust Me, I used to be a doctor!"; love, the love of my wife and family and friends. Also my spirituality has become the centre point of my life and to that extent my church community has replaced the medical community for my daily sustenance. The following may sound trite, but it is true: I may not know what the future holds, but I know who holds the future.

May I leave you with following challenges which I hope we can discuss.

a) See the person in the patient. It's often said and is very true that small acts of kindness and empathy make all the difference in the world. Your patients need both your clinical competence and your compassion. Words matter, especially those imbued with denigration. ${ }^{(5)}$

b) The job of any health-care professional working for older adults is to recognize and refute ageism wherever it occurs. On a personal note, it was one thing to be an advocate for older people, quite another to actually be living it. And though ageing may seem so remote when one is young, suddenly it happens and life changes.

c) Enjoy working for older adults personally and professionally. For me it was always intellectually challenging, emotionally rewarding, and collegially satisfying.

Here's a final question for you: How do you help older people deal with their issues of fear and loss?

At the end of my lecture I became so excited that I thought I should re-train as a geriatrician!

Now, let's come back to my question to you at the beginning: What's an alternative to the statement that "old age is not for sissies"? One answer is, "Old age takes courage!"

\section{ACKNOWLEDGEMENTS}

I thank Ann, my wife, specifically for her help with this preparation and generally for her role as my helper and supporter; David Hogan, professor and acting head of Geriatric Medicine at this university for his advice to me and my medical attendants; our friend Janet Hogan for the immeasurable support she has given to Ann and me through this journey; and lastly, thanks to the Calgary Chapter of AAG for this challenge and opportunity.

\section{CONFLICT OF INTEREST DISCLOSURES}

The author declares that no conflicts of interest exist.

\section{REFERENCES}

1. Powell C, Mitchell-Pedersen L, Fingerote E, et al. Freedom from restraint: consequences of reducing physical restraints in the management of the elderly. CMAJ. 1989;141(6):561-64.

2. Powell C. Parkinson's disease in old age, Part 1Similarities and differences. Can J Gen Int Med. 2008;3(3):141-42. 
3. Powell C. Parkinson's disease in old age: Part 2-What happens when the pills start to fail? Can J Gen Int Med. 2008;3(4):178-79.

4. Corbin J, Strauss A. Carers: working together. Nurs Times. 1988;84(15):48-49.
5. Andrew MK, Powell C. An approach to 'The Social Admission’. Can J Gen Int Med. 2015;10(4):20-22.

Correspondence to: Colin Powell, MB, FRCP, Professor of Geriatric Medicine (retired), University of Calgary, 2500 University Dr. NW, Calgary, AB T2N 1N4, Canada E-mail: ccpowell@ucalgary.ca 